\title{
EFEKTIVITAS PROGRAM BEASISWA BIDIKMISI DI UNIVERSITAS NEGERI SURABAYA
}

\author{
Dwi Harmani Astuti D. \\ Amin Fauzi \\ Samsuruhuda $\mathrm{H}$. \\ Universitas Negeri Surabaya \\ E-mail: dha dewi22@yahoo.co.id
}

\begin{abstract}
The focus of the study is to determine the effectiveness of 'Bidikmisi' scholarship program implementation at Universitas Negeri Surabaya (Unesa). This qualitative research uses a case study approach to find wider and deeper understanding of the data collected. The data collection methods are through interviews, observations, and documentations. Research data is then analysed to define the efficacy of 'Bidikmisi'at Unesa. The results of the study imply that Unesa has implemented government policy to provide access to higher education to people with low economic backgrounds. The effectiveness of 'Bidikmisi' at Unesa is based on the accomplishment of the program objectives, explicitly (1) equitable access to education, (2) numbers of on time graduates, and (3) students increasing achievements. The result of the research data analysis has shown that Bidikmisi program is effectively implemented at Unesa. Factors inhibit to the enactment of the program at Unesa are the lack of coordination between the program managers and related units, less information to Bidikmisi recipients, incomplete monitoring and evaluation process, and less committed Bidikmisi recipients to their individual responsibility.
\end{abstract}

Keyword: effectivity, program, scholarship, bidikmisi.

\begin{abstract}
Abstrak: Fokus penelitian ini adalah untuk mengetahui efektivitas penyelenggaraan rogram beasiswa bidikmisi di Universitas Negeri Surabaya. Penelitian ini adalah penelitian kualitatif dengan pendekatan studi kasusuntuk memperoleh pemahaman yang lebih luas dan mendalam terhadap data yang ditemukan dan dihadapi peneliti.Metode pengumpulan data penelitian melalui wawancara, observasi, dan dokumentasi.Data kemudian dianalisis untuk mengetahui bagaimana efektifitasprogram beasiswa Bidikmisi di Universitas Negeri Surabaya. Hasil penelitian ini menunjukkan bahwa Universitas Negeri Surabaya telah berperan sebagai pelaksana kebijakan pemerintah memberikan akses pendidikan tinggi kepada masyarakat yang memiliki keterbatasan ekonomi. Efektivitas program bidikmisi di Universitas Negeri Surabaya didasarkan atas capaian beberapa tujuan bidikmisi yaitu (1) pemerataan akses pendidikan, (2) lulus tepat waktu, dan (3) meningkatkan prestasi.Berdasarkan data hasil penelitian menunjukkan sudah efektif. Faktor penghambat yang ditemui dalam pengelolaan bidikmisi di Unesa antara lain kurangnya koordinasi antara pengelola dengan pihak-pihak terkait, kurangnya informasi dan komunikasi yang diberikan kepada penerima bidikmisi, masih belum terlaksananya monitoring dan evaluasi, dan kurangnya komitmen penerima bidikmisi atas tanggungjawabnya sebagai penerima bidikmisi
\end{abstract}

Kata kunci: efektivitas, program, beasiswa, bidikmisi

\begin{abstract}
Undang-Undang Republik Indonesia Nomor 12 Tahun 2013 tentang Sistem Pendidikan Nasional menyebutkan bahwa Setiap warga negara mempunyai hak yang sama untuk memperoleh pendidikan yang bermutu. Salah satu program pemerintah untuk mewujudkan amanat undang-undang tersebut adalah pemberian bantuan dana kepada masyarakat untuk pendidikan tinggi, yaitu bantuan biaya pendidikan Bidikmisi.
\end{abstract}

Bantuan biaya pendidikan ini diberikan karena masih banyak lulusan SMA/SMK/MA tidak mampu untuk melanjutkan pendidikan ke jenjang yang lebih tinggi karena faktor keterbatasan ekonomi orang tua, padahal mereka mempunyai potensi akademik yang baik.Kondisi ekonomi yang sulit ini menjadi sumber utama dalam pemerataan akses pendidikan tinggi.Bagi mereka pendidikan tinggi adalah sesuatu yang 
tinggi untuk dapat diakses.Biaya kuliah tinggiadalah beban bagi mereka yang tidak mampu secara ekonomi.

Pemerintah melalui Kementerian Riset, Teknologi, dan Pendidikan Tinggi (Kemenristekdikti) sebagai penyelenggara bantuan biaya pendidikan Bidikmisi diharapkan mampu memberikan akses pendidikan tinggi kepada masyarakat miskin, sehingga dapat memutus rantai kemiskinan. Skema bantuan biaya pendidikan Bidikmisi adalah memberikan jaminan pembiayaan mulai dari pendaftaran sampai luluskuliah, termasukpemberian subsidi biaya hidup. Penyelenggaraannya dengan Prinsip 3T yaitu tepat sasaran, tepat jumlah, dan tepat waktu, sehingga manfaatnya dapat dirasakan oleh penerima Bidikmisi dan tujuan pemberian bantuan biaya pendidikan Bidikmisi ini dapat tercapai. Namun demikian penyelenggaraan Bidikmisi ini tidak terlepas dari problematika, mahasiswa Bidikmisi tidak lulus tepat waktu, penggunaan dana biaya hidup mahasiswa yang tidak relevan, penerima tidak tepat sasaran, pencairan dana tidak tepat waktu, data penerima yang tidak valid, mekanisme penggantian penerima bidikmisi kurang jelas, termasuk nilai indek prestasi dibawah standar.

Universitas Negeri Surabaya (Unesa) adalah salah satu universitas yang menerima mahasiswa Bidikmisi.Saat ini jumlah mahasiswa Bidikmisi Unesa sebanyak 5.247 mahasiswa.Berdasarkan data mahasiswa Bidikmisi di Unesa dan permasalahan pengelolaan Bidikmisi tersebut di atas, maka perlu dilaksanakan penelitian tentang bagaimana penyelenggaraan bantuan biaya pendidikan Bidikmisi Universitas Negeri Surabaya. Penelitian ini bertujuan untuk mengetahui efektivitas bantuan biaya pendidikanBidikmisi di Unesa, faktor penghambat penyelenggaraan bantuan biaya pendidikanBidikmisi.

Suatu program dapat dikatakan efektif apabila dapat mencapai tujuan yang diharapkan dan berdampak secara positif bagi sasaran program (Hermawati, 2011).

Pemerintah melalui Direktorat Jenderal Pembelajaran dan Kemahasiswaan, Kementerian Riset Teknologi dan Pendidikan Tinggi mulai tahun 2010 meluncurkan Program Bantuan Biaya Pendidikan Bidikmisi (Sandra, 2017).

(Mahmudi, 2005) menyatakan bahwa efektivitas merupakan hubungan antara output dengan tujuan, semakin besar kontribusi output terhadap pencapaian tujuan, maka semakin efektif organisasi, program atau kegiatan". Suatu organisasi atau program kebijakan dinilai efektif apabila output yang dihasilkan bisa memenuhi tujuan yang diharapkan. Bantuan biaya pendidikan Bidikmisi adalah salah satu kebijakan pemerintah Indonesia sebagaimana tertuang dalam pasal 74 Undang-Undang Republik Indonesia Nomor 12 Tahun 2012 tentang Pendidikan Tinggi, dan Peraturan Menteri Riset, Teknologi, dan Pendidikan Tinggi Republik Indonesia Nomor 6 Tahun 2019 tentang Bantuan Biaya Pendidikan bagi Mahasiswa Miskin Berprestasi.Kebijakan tersebut untuk memberikan akses pendidikan pada masyarakat.Kebijakan publik adalah sebagai hubungan suatu unit pemerintah dengan lingkungannya .Menurut (Edward, 1980) mendefenisikan kebijakan publik sebagai suatu tindakan pemerintah yang berupa programprogram pemerintah untuk pencapaian sasaran atau tujuan.Kebijakan publik adalah serangkaian tindakan yang dilakukan atau tidak dilakukan oleh pemerintah yang berorientasi pada tujuan tertentu guna memecahkan masalahmasalah publik atau demi kepentingan public (Salusu, 1996).

Tujuan pemberian beasiswa pada dasarnya adalah untuk mendukung kemajuan dunia pendidikan, pemerataan kesempatan belajar bagi generasi yang berprestasi dan kurang kurang mampu secara ekonomi, mendorong dan mempertahankan semangat belajar mahasiswa sehingga mampu tetap berprestasi dan bergairah dalam menyelesaikan studi, serta mendorong siswa berpacu mencapai prestasi akademik yang tertinggi sehingga sumberdaya manusia yang potensial tersebut tidak sia-sia. Sama halnya dengan bantuan biaya pendidikan Bidikmisi, yaitu memperluas akses pendidikan tinggi bagi masyarakat yang mempunyai kemampuan akademik tinggi namun keadaan ekonomi keluarga tidak 
mampu. Adapun kriteria penerima bantuan biaya pendidikan bidikmisi antara lain 1) Pemegang Kartu Indonesia Pintar (KIP) atau sejenisnya, 2) Pendapatan kotor gabungan orangtua/wali (suami istri) sebesar-besarnya Rp 4.000.000,- per bulan. Untuk pekerjaan non formal/informal pendapatan yang dimaksud adalah rata-rata penghasilan per bulan dalam satu tahun terakhir; dan atau 3) Pendapatan kotor gabungan orangtua/wali dibagi jumlah anggota keluarga sebesar-besarnya Rp 750.000,setiap bulannya.

Bidikmisi adalah bantuan biaya pendidikan dari Kementerian Riset Teknologi dan Pendidikan Tinggi Republik Indonesia yang memberikan fasilitas pembebasan biaya pendidikan dan subsidi biaya hidup. Bidikmisi diberikan kepada penerima selama delapan semester untuk program Strata Satu (S-1) atau Diploma 4 (D-4), enam semester untuk program Diploma Tiga (D-3), empat semester untuk program Diploma Dua (D2), dan dua semester untuk program Diploma Satu (D-1). Adapun besaran subsidi biaya hidup yang diberikan serendah-rendahnya adalah Rp 750.000,per bulan, diberikan kepada mahasiswa setiap semester (6 bulan). Sedangkan pembebasan biaya pendidikan mencakup semua biaya yang dibayarkan ke Perguruan Tinggi untuk kepentingan pendidikan.Misi utama Bidikmisi adalah memutus mata rantai kemiskinan dengan memberikan akses pendidikan tinggi untuk masyarakat Indonesia yang miskin, namun memiliki prestasi akademik yang baik.Hal ini diharapkan mampu menguatkan nilai-nilai kebangsaan, patriotisme, cinta tanah air, dan semangat bela negara.

Adapun tujuan Bidikmisi adalah 1) meningkatkan akses dan kesempatan belajar di Perguruan Tinggi bagi peserta didik yang ispetidak mampu secara ekonomi dan memiliki prestasi akademik yang baik; 2)meningkatkan prestasi mahasiswa, baik pada bidang kurikuler, kokurikuler, maupun 3) Menimbulkan dampak iring bagi mahasiswa dan calon mahasiswa lain untuk berkarakter selalu meningkatkan prestasi, 4) Melahirkan lulusan yang mandiri, produktif, dan memiliki kepedulian sosial, sehingga isepimampu berperan dalam upaya pemutusan mata rantai kemiskinan dan pemberdayaan masyarakat.

Persyaratan penerima bidikmisi baru mengacu pedoman penerimaan bidikmisi yang diterbitkan oleh Kemensristekdikti yaitucalon penerima Bidikmisi adalah lulusan SMA/SMK/MA/MAK dan sederajat yang memiliki syarat sebagai berikut (1) Pendapatan kotor orang tua/wali gabungan (suami+istri) setinggi-tingginya Rp 4.000.000,- (empat juta rupiah) atau pendapatan kotor gabungan orangtua/wali dibagi jumlah anggota keluarga maksimal Rp 750.000,- (tujuh ratus lima puluh ribu rupiah), (2) Belum pernah ditetapkan sebagai penerima Bidikmisi di salah satu PT di bawah Ristekdikti, (3) Belum pernah menjadi mahasiswa di PT Penyelenggara Bidikmisi di tahun ajaran sebelumnya, (4) Lulus seleksi masuk yang memberikan fasilitas Bidikmisi, seperti SNMPTN, SBMPTN, dan seleksi lain yang ditetapkan oleh masing-masing panitia dan PT Penyelenggara. is ispiawal diterima sebagai mahasiswa penerima bidikmisi diharuskan membuat surat pernyataan yang berisikan tentang hal-hal penting sebagai bentuk tanggungjawab dan integritas penerima bidikmisi. Dalam pernyataan tersebut disebutkan hal-hal sebagai berikut (1) menjunjung tinggi Negara Kesatuan Republik Indonesia (NKRI) berdasarkan Pancasila dan UUD 1945, (2) berperan aktif dan berkontribusi dalam pelaksanaan Tridarma Perguruan Tinggi Universitas Negeri Surabaya, (3) berperilaku sesuai etika mahasiswa Universitas Negeri Surabaya, meningkatkan dan melaporkan prestasi akademik per semester kepada pengelola Bidikmisi Universitas Negeri Surabaya, (5) berusaha lulus tepat waktu sesuai masa bantuan biaya pendidikan Bidikmisi.

\section{METODE}

Penelitian ini adalah penelitian kualitatif dengan pendekatan studi kasus yang bertujuan membuat deskripsi atau gambaran secara sistematis, faktual, dan akurat mengenai fakta-fakta serta hubungan antar fenomena yang diteliti 
(Moleong, 2014). Penelitian ini akan dilaksanakan di Universitas Negeri Surabaya dengan mempertimbangkan bahwa Universitas Negeri Surabaya adalahsalah satu universitas yang menyelenggarakan kebijakan pemerintah pemberian bantuan pendidikan Bidikmisi. Sumber data dalam penelitian ini sebagai berikut (1) data primer yaitu data berada di lokasi penelitian yang diperoleh secara langsung melalui observasi dan wawancara kepada responden atau informan mengenai penyelenggaraan program beasiswa bidikmisi di Unesa. (Asra et al., 2015) Informan penelitian merupakan pihak-pihak yang dapat memberikan informasi mengenai situasi dan kondisi yang ada sehingga data yang dihasilkan dapat akurat dan terpercaya. Informan dalam penelitian ini adalah sebagai berikut (a) Informan utama, yaitu orang yang terlibat langsung dalam interaksi sosial yang diteliti. Informan utama dalam penelitian ini adalah tujuh orang Mahasiswa Bidikmisi yang berasal dari tujuh fakultas di Unesa, (b) Informan Kunci (key informan) adalah orang yang mengetahui dan memiliki informasi pokok yang diperlukan dalam penelitian yaitu Kepala Biro Akademik, Kemahasiswaan, Perencanaan, dan Kerjasama (BAKPK) Unesa dan Kepala Bagian Kemahasiswaan, BAKPK Unesa, (c) Informan Tambahan, adalah orang yang tidak terlibat langsung dalam objek yang diteliti. Informan tambahan dalam penelitian ini adalah tiga orang Mahasiswa Non Bidikmisi. (2) Data sekunder yaitu data yang diperoleh dari literasi, buku pedoman, peraturan, jurnal ilmiah, buku, laporan hasil penelitian, maupun dokumen pengelolaan program beasiswa bidikmisi di Universitas Negeri Surabaya.

Metode pengumpulan data yang digunakan yaitu wawancara, dokumentasi, dan studi kepustakaan.Analisis data dilakukan dengan menggunakan metode Miles and Huberman dengan langkah penyelesaian terdiri atas reduksi data, penyajian data, dan penarikan kesimpulan (Herdianysah, 2010).Guna memastikan keabsahan data penelitian dilakukan triangulasi (Baskoro, 2016). Menurut (Sugiyono, 2012) triangulasi dapat diartikan sebagai pengecekan data dari berbagai sumber dengan berbagai cara, berbagai waktu. Peneliti dapat membandingkan data hasil pengamatan dengan data hasil wawancara, membandingkan apa yang dikatakan orang di depan umum dengan apa yang dikatakan secara pribadi, membandingkan apa yang dikatakan orang-orang tentang situasi penelitian dengan apa yang dikatakannya sepanjang waktu, membandingkan keadaan dan perspektif seseorang dengan berbagai pendapat dan pandangan orang lain dan membandingkan hasil wawancara dengan isi suatu dokumen yang berkaitan.

\section{HASIL}

Universitas Negeri Surabaya (Unesa) sebagai Lembaga Pendidikan Tenaga Kependidikan (LPTK) mengalami perubahan status dari Institut Keguruan dan IImu Pendidikan (IKIP) Surabaya yang berdiri pada tahun 1964.Berdasarkan Keppres Nomor 93/1999 tentang Perubahan IKIP menjadi Universitas, bahwa IKIP Surabaya berubah menjadi Universitas Negeri Surabaya (Unesa). Unesa mengelola tujuh fakultas dan pascasarjana, yaitu (1) Fakultas IImu Pendidikan (FIP), (2) Fakultas Bahasa dan Seni (FBS), (3) Fakultas Matematika dan IImu Pengetahuan Alam (FMIPA), (4) Fakultas IImu Sosial (FIS), (5) Fakultas Teknik (FT), (6) Fakultas Ilmu Keolahragaan (FIK), dan (7) Fakultas Ekonomi. Sebagai salah satu universitas eks LPTK, menyelenggarakan program kependidikan dan mengembangkan program nonkependidikan.

Unesa sebagai lembaga pendidikan tinggi menjalankan amanat UUD 1945 bidang pendidikan, yaitu mencerdaskan kehidupan bangsa dengan memberikan akses seluas-luasnya kepada semua warga negara untuk mendapatkan haknya dalam pendidikan.Pendidikan merupakan hak asasi bagi setiap warga Negara Indonesia,sehingga Unesa memberikan layanan pendidikan berkualitas dan berkeadilan bagi setiap warga Negara.Pemerataan akses dan peningkatan mutu pendidikan akan membuat warga negara Indonesia 
memiliki kecakapan hidup (life skills) sehingga mendorong tegaknya pembangunan manusia seutuhnya serta masyarakat madani dan modern yang dijiwai nilai-nilai Pancasila, sebagaimana diamanatkan dalam Undang-Undang Republik Indonesia Nomor 20 Tahun 2003 tentang Sistem Pendidikan Nasional.

Deskripsi data hasil penelitian dan informan tentang efektivitas pengelolaan beasiswa Bidikmisi di Universitas Negeri Surabaya, sebagai berikut.

\section{Pemerataan akses}

Bidikmisi adalah salah satu program pemerintah yang merupakan bentuk kepedulian pemerintah kepada masyarakat dengan pertimbangan utamanya adalah kemampuan ekonomi di bawah rata-rata atau ekonomi rendah. Hal ini dilaksanakan untuk mencapai tujuan yaitu terwujudnya masyarakat dengan ekonomi terbatas namun dapat mengakses pendidikan tinggi.Keseriusan perguruan tinggi dalam mengelola Program Bidikmisi agar dapat terdistribusi dengan baik kepada mahasiswa penerima Bidikmisi dapat dilihat dari keseriusannya dalam memberdayakan mahasiswanya.

Bentuk seriusnya Unesa dalam melayani mahasiswa Bidikmisi supaya memperoleh akses pendidikan dirasakan oleh salah seorang penerima Bidikmisi seperti yang dikutip dari hasil wawancara berikut.

Saya bangga dan sudah dapat merasakan manfaat dari pemberian bantuan biaya pendidikan Bidikmisi yang diberikan oleh pemerintah. Saya dapat mengenyam pendidikan tinggi di Unesa ini,akanSaya manfaatkan dengan sebaik-baiknya kesempatan ini dan berusaha mencapai prestasi yang baik. Alhamdulillah Saya juga sudah berpartisipasi sebagai penulis PKM yang didanai Dikti dan lolos mengikuti PIMNAS 32 tahun 2019 di Bali. (Wawancara dengan Nurul Hidayat, FIO, 5 September 2019)

Sesuai dengan petikan wawancara di atas, untuk memastikan calon penerima bantuan biaya pendidikan bidikmisi sesuai sasaran yaitu dari keluarga miskin, maka Unesa melakukan verifikasi lapangan atau survei untuk melihat kondisi sesungguhnya berdasarkan alamat yang ada di data calon mahasiswa. Hasil survei akan digunakan untuk menetapkan layak atau tidak layak calon mahasiswa bidikmisi. Berdasarkan data surveitersebut, bahwa sebagian besar hasilnya adalah layak dan tepat sasaran. Apabila ada calon penerima bidikmisi tidak sesuai kondisi yang ada atau tidak tepat sasaran, maka akan dilakukan pengalihan kepada mahasiswa yang membutuhkan atau yang lebih layak. Survei lapangan ke rumah atau ke alamat calon penerima bidikmisi adalah salah satu strategi yang dilaksanakan Unesa untuk memastikanBidikmisi tepat sasaran.Hal ini seiring dengan pernyataan yang disampaikan narasumber, sebagai berikut.

Agar penyaluran bidikmisi ini sesuai dengan rencana sasaran yaitu mengentaskan kemiskinan dan memutus rantai kemiskinan, sehingga diawal setelah mereka dinyatakan diterima selanjutnya oleh Unesa dilakukan verifikasi data melalui cek lapangan, apakah memang yang bersangkutan layak mendapatkan bidikmisi atau tidak. Maka strategi yang digunakan adalah dengan mendatangi rumah masingmasing.(Wawancara dengan Dra. Ratih Pudjiastuti, M.Si. Kepala BAKPK, 29 Agustus 2019)

Lebih lanjut dalam petikan wawancara narasumber menyampaikan, bahwa.

Berdasarkan pagu yang diterima menurut Saya bisa dikatakan tepat sasaran, memang ketika kita survey lapangan sebagian besar memang kondisinya sebagai masyarakat yang kurang mampu. Tetapi ada juga sekian persen (sangat kecil) menurut Saya yang memang tidak layak untuk diberi beasiswa bidikmisi, dan itu biasanya akan dialihkan kepada mahasiswa yang lebih membutuhkan. Secara keseluruhan sudah sesuai sasaran yang ditentukan oleh Pemerintah, (Wawancara dengan Dra. Ratih Pudjiastuti, M.Si. Kepala BAKPK, 29 Agustus 2019).

Senada dengan yang disampaikan narasumber di atas, bahwa ketepatan sasaran penerima bidikmisi di Unesa mencapai $95 \%$. Hal ini diungkapkan oleh narasumber dalam kutipan wawancara sebagai berikut. 
Bahwa 95\% penerima bantuan biaya pendidikan bidikmisi berdasarkan kuota yang telah ditetapkan oleh Ditjen Belmawa Kemenristekdikti adalah tepat sasaran, hal ini dipastikan dengan dilakukan verifikasi berkas dan verifikasi lapangan oleh pihak kampus Unesa. (Wawancara dengan Bapak Suyanto, Kabag Kemahasiswaan, 3 September 2019).

Apa yang sudah disampaikan oleh narasumber di atas juga sejalan dengan yang disampaikan oleh narasumber dari mahasiswa nonbidikmisi, sebagai berikut.Untuk teman-teman Saya yang menerima Beasiswa Bidikmisi sudah tepat sasaran, karena keadaannya temanteman saya sangat membutuhkan, ada sekitar 5 atau 7 anak dikelas saya sangat membutuhkan, untuk bayar-bayar agak susah. Penerima bidikmisi, mereka ada yang bekerja dan jualan, kalau menurut Saya sudah tepat kalau di jurusan atau dikelas Saya khususnya.Dan yang Saya tahu,ada beberapa bergaya hidupnya lebih. Ada kelas lain penerima bidikmisi gaya hidupnya wah, kata teman-teman Saya, keadaan aslinya mereka memang membutuhkan.(Wawancara dengan Chintya Dyah Ayu, FIP, 15 Oktober 2019).

Namun, data dilapangan menunjukan bahwa terdapat beberapa mahasiswa Bidikmisi secara penampilan dinilai tidak mencerminkan sebagai sosok mahasiswa Bidikmisi.Hal ini seperti yang dinyatakan dalam kutipan wawancara narasumber penerima bidikmisi sebagai berikut.

Sebenarnya menurut Saya untuk penerima bidikmisi Saya rasa belum tepat sasaran, karena apa? Disini Saya itu sering melihat bukan hanya teman Saya saja tetapi kakak tingkat Saya yang bidikmisi banyak yang kehidupannya itu mewah, mereka pakai barang-barang branded, tetapi yang Saya herankan meraka itu penerima bidikmisi, sedangkan teman-teman saya yang nasibnya kurang beruntung malah tidak terima, bahkan mereka itu mendapat UKT K2. Teman Saya ada yang anak dari pedagang asongan dengan UKT K2 jadi harus membayar 1 Juta, membuat dia terpontang panting supaya dapat beasiswa kesana kemari demi membayar UKT nya. Kalau di FISH Saya kurang paham berapa persen yang tidak tepat sasaran, tetapi kalau yang di jurusan Saya paham.(Wawancara dengan Mei Zuliawati, Penerima BM FISH, pada 10 Oktober 2019).

Berdasarkan hasil penelitian ini menunjukkan bahwa program pemberian bantuan biaya pendidikan bidikmisi $95 \%$ tepat sasaran. Program Bidikmisi mampu mengangkat masyarakat ekonomi terbatas dapat memperoleh kesempatan belajar pada jenjang pendidikan yang lebih tinggi yaitu kuliah di perguruan tinggi. Sehingga dengan demikian dapat dikatakan bahwa bantuan biaya pendidikan Bidikmisi mampu menjawab persoalan pemerataan akses pendidikan di Indonesia.

Program bantuan biaya pendidikan Bidikmisi yang diselenggarakan di Unesa telah dapat dirasakan manfaatnya oleh mahasiswa penerima bidikmisi, antara lain terbentuknya kebanggaan dan rasa percaya diri mereka dapat menempuh kuliah, yang tentu sebelumnya tidak pernah mereka bayangkan. Manfaat lainnya adalah penerima bidikmisi merasa dapat meringankan beban orang tua dan beban keluarga, meskipun sesungguhnya biaya bidikmisi dirasakan kurang untuk memenuhi kebutuhan perkuliahan. Hal ini sesuai dengan yang diungkapkan (Hermawati, 2011) bahwa salah satu aspek yang mampu membuktikan kebijakan sosial dikatakan efektif adalah apabila masyarakat dapat menikmati hasil program.

\section{Lulus tepat waktu}

Pengelolaan bantuan biaya pendidikan Bidikmisi dilakukan oleh Unesa sejak program ini diluncurkan yaitu tahun 2010, selama ini Unesa mengelola Bidikmisi dengan baik.Pengelola Bidikmisi berperan secara aktif dalam menyusun kegiatan pengelolaan dengan melibatkan pihak-pihak terkait, mulai dari pimpinan universitas sampai dengan staf. Keterlibatan pihak terkait ini untuk mendukung agar mahasiswa penerima Bidikmisi dapat melaksanakan tugas dan tanggungjawab selesai tepat waktu sesuai dengan jangka waktu Bidikmisi yang ada Unesa, yaitu selama delapan semester untuk program Strata Satu (S-1) atau 
Diploma 4 (D-4), enam semester untuk program Diploma Tiga (D-3). Untuk mendorong agar mahasiswa Bidikmisi Unesa lulus tepat waktu,maka pelu dilakukan monitoring evaluasi Bidikmisi setiap semester yaitu untuk memantau hasil studi penerima bidikmisi. Apabila ada mahasiswa bidikmisi yang nilainya IPK kurang dari 3.00 atau tidak melaksanakan perkuliahan maka akan dipanggil untuk ditanyakan hasil studinya, apakah ada kendala, dan akan diminta untuk memperbaiki di semester selanjutnya. Namun apabila antara IPK dan SKS yang telah ditempuh masih jauh dari standard atau normalnya kuliah maka akan diberikan sanksi untuk diberhentikan bidikmisinya.

Komitmen mahasiswa Bidikmisi juga sangat penting, mahasiswa harus mempu memanfaatkan peluang yang telah diberikan oleh pemerintah.Komitmen tersebut dapat terlihat dari keseriusan mahasiswa Bidikmisi dalam menyelesaikan masa studinya, bagaimana mahasiswa Bidikmisi dapat termotivasi atas Bidikmisi yang diterima. Dalam hal ini kesadaran akan tanggungjawab mahasiswa Bidikmisi dalam menyelesaikan masa studinya tepat waktu.

Berdasarkan data hasil penelitian ini menunjukkan bahwa para penerima Bidikmisi merasa termotivasi dan bangga dapat menempuh kuliah, serta termotivasi untuk dapat menyelesaikan studi dengan baik dan tepat waktu, seperti yang disampaikan narasumber dalam petikan wawancara berikut.

Ya, kalau menurut Saya ada kaitannya, kenapa? Karena penerima BM inikan mendapat beasiswa dari pemerintah dan pastinya dana tersebut diperoleh dari pajak-pajak yang dibayar dari rakyat dan ketika mahasiswa penerima BM itu sudah melaksanakan pendidikan kalau mereka hanya santai santai saja menurut Saya tidak ada feedback yang diberikan ketika sudah menerima beasiswa BM itu. Tetapi kalau sudah terima beasiswa BM seperti Saya pribadi maka Saya harus bertanggungjawab dengan apa yang telah saya terima, ya otomatis itu berkaitan dengan motivasi Saya untuk terus meningkatkan prestasi Saya (Wawancara dengan Marselina Santoso, Penerima BM FBS, 12 September 2019)

Senada dengan yang disampaikan narasumber di atas, narasumber yang lain dari mahasiswa Bidikmisi menyampaikan bahwa berkomitmen untuk melaksanakan tanggungjawab dan lulus tepat waktu, bahwa lebih cepat dari masa yang diberikan, berikut petikan hasil wawancara sebagai berikut.

Ada kaitannya, Saya jika tidak menerima bidikmisi nggak mungkin Saya kuliah, maka Saya harus memanfaatkan BM dengan baik, kalau bisa lulus tepat waktu dan berusaha untuk lulus 3.5 tahun, sehingga tidak menyusahkan Unesa dan orang tua (Wawancara dengan Mei Zuliawati, Penerima BM FISH, 10 Oktober 2019).

Program Bidikmisi ini salah tujuannya adalah menjamin keberlangsungan studi mahasiswa tepat waktu. Berdasarkan data yang diperoleh dari BAKPK, tingkat lulus tepat waktu mahasiswa Bidikmisi masih belum sesuai dengan harapan yaitu lulus delapan semester.Penerima Bidikmisi angkatan tahun 2015 jumlah penerima sebanyak 1150 orang, lulus tepat waktu sebanyak 574 orang atau sebanyak 49.91\%. Hal tersebut sejalan dengan yang disampaikan narasumber dalam kutipan wawancara berikut.

Berbicara masalah lulus tepat waktu untuk mahasiswa bidikmisi, ada sebagian yang memang empat tahun sudah lulus, bahkan sering kali yang wisudawan terbaik dari bidikmisi juga ada.Namun tidak dapat dipungkiri juga yang masa studinya lebih dari delapan semester itu juga banyak. Harapannya bahwa mereka yang dapat bidikmisi dapat selesai sesuai jatahnya yaitu delapan semester, supaya dia benar-benar dapat meningkatkan prestasinya. Satu sisi ada yang selesai tepat waktu, disisi lain ada yang tidak tepat waktu, sehingga perlu ada sentuhan lain agar mereka bisa selesai tepat waktu. (Wawancara dengan Dra. Ratih Pudjiastuti, M.Si. Kepala BAKPK, 29 Agustus 2019). Seiring dengan yang disampaikan oleh Kepala BAKPK di atas, bagi penerima bidikmisi yang tidak dapat menyelesaikan masa studinya dengan tepat waktu.maka mereka akan alihkan 
sebagai mahasiswa regular dengan membayar uang kuliah tunggal (UKT).

Kebijakan publik dapat dilihat keberhasilannya salah satunya diukur dengan melihat tanggapan atau respon pelaksana kebijakan maupun sasaran penerima kebijakan tersebut, baik respon postif maupun respon negatif. Berdasarkan data penelitian ini menunjukkan bawa pelaksana kebijakan (pengelola) Bidikmisi Unesa memberikan respon positif atas program Bidikmisi. Adanya sinergi lintas bagian di Unesa terkait Bidikmisi menunjukkan bahwa pelaksana layanan administrasi Unesa mendukung suksesnya Bidikmisi, namun demikian Unesa masih perlu terobosan pengelolaan Bidikmisi.Mahasiswa Bidikmisi Unesa masih perlu didorong dan diberikan motivasi agar mampu membuktikan lulus kuliah tepat waktu sesuai dengan masa studi yang diberikan program bidikmisi.

\section{Meningkatnya prestasi dan kualitas mahasiswa}

Program Bidikmisi selain memberikan kesempatan kepada masyarakat ekonomi kurang mampu dapat menempuh pendidikan tinggi, Bidikmisi juga mempunyai tugas menghasilkan lulusan berkualitas sehingga mampu memutus rantai kemiskinan keluarga, sehinggamampu menaikkan tingkat kesejahteraan masyarakat. Mahasiswa bidikmisi tentu sudah bisa merasakan manfaat program bidikmisi.Banyak manfaat yang bisa dirasakan bagi penerima bidikmisi, seperti yang disampaikan narasumber dalam petikan wawancara berikut.

Ya alhamdulillah Saya sangat merasakan manfaat, karena Saya saat ini sudah tidak punya Bapak jadi Saya merasa sangat terbantu sekali jadi orang tua saya (ibu) biar fokus memikirkan dan membiayai adik-adik saya, saya merasa sudah terbantu dari Bidikmisi ini (Wawancara dengan Marselina Santoso, Penerima BM FBS, 12 September 2019).

Mendukung pernyataan penerima Bidikmisi di atas, penerima lainnya menyatakan hal yang sama, seperti pernyataan hasil wawancara berikut.

Banyak sekali manfaatnya, antara lain
Saya bisa kuliah, dapat meringankan beban orang tua, bisa membeli buku, bisa membayar kost. Secara prinsip saya sudah dapat merasakan manfaat bidikmisi yang Saya terima (Wawancara dengan Mei Zuliawati, Penerima BM FISH, 10 Oktober 2019).

Adanya fasilitas dan kemudahan untuk mengenyam pendidikan tinggi adalah mimpi yang dapat diwujudkan dengan semangat dan komitmen yang kuat dari penerima Bidikmisi.Hal ini senada dengan yang diungkapan oleh narasumber dalam kutipan wawancara sebagai berikut.

Namanya saja banyak anak, artinya bedabeda personil pasti beda perlakukan. Tetapi ketika kita bilang lulusan tepat waktu ada sebagain yang memang sebelum 4 tahun sudah lulus, bahkan seringkali yang wisuda terbaik itu bidikmisi ada, tetapi tidak menutup kemungkinan juga yang lebih dari delapan semester itu juga banyak, sehingga harapannya ketika dia mendapatkan bidikmisi itu delapan semster itu harus selesai, supaya dia benar-benar dapat meningkatkan prestasinya. Disatu sisi berhasil di sisi yang lain perlu ada sentuhan lain supaya anak-anak bidikmisi bisa lulus tepat waktu (Wawancara dengan Dra. Ratih Pudjiastuti, M.Si. Kepala BAKPK, 29 Agustus 2019)

Selain prestasi akademik untuk melihat prestasi nonakademik mahasiswa Bidikmisi dapat dilihat dari keterlibatan mahasiswa Bidikmisi dalam organisasi kemahasiswaan dan kegiatan-kegiatan kemahasiswaan lainnya, seperti yang disampaikan dalam petikan wawancara berikut.

Ada, karena kita sudah diberi kesempatan oleh pemerintah dan kita dituntut untuk dapat berprestasi, baik dari sisi akademik maupun nonakademik selama masa empat tahun. Seperti Saya ini mempunyai prestasi di bidang olahraga bola tangan, pernah menyusun Program Kreativitas Mahasiswa (PKM), dan Alhamdulillah dapat mewakili Unesa untuk mengikuti PIMNAS meskipun belum dapat juara. Saya ingin mengikuti Program Mahasiswa Wirausaha (PMW) (Wawancara dengan Nurul Hidayat, FIO, 3 September 2019)

Untuk meningkatkan prestasi dan 
kualitas mahasiswa penerima Bidikmisi di Unesa dilakukan kegiatan pembekalan dan pelatihan sehingga mahasiswa Bidikmisi semakin banyak pengalaman dan meningkat kompetensinya.Diawali dengan kegiatan pelatihan Pendidikan Karakter yang dilaksanakan dengan tujuan untuk peningkatan kemampuan mahasiswa, cinta tanah air, dan rasa kebangsaan.Pelatihan selanjutnya pelatihan Karya Tulis IImiah (PKTI).Pelatihan ini untuk memberikan pengetahuan dan keterampilan mahasiswa Bidikmisi Unesa untuk menulis proposal Program Kreativitas Mahasiswa (PKM).Pelatihan berikutnya yaitu Kewirausahaan, tujuannya adalah memberikan bekal kemampuan wirausaha pada mahasiswa Bidikmisi yang akan lulus sehingga siap untuk mandiri di masyarakat.

\section{PEMBAHASAN}

\section{Faktor penghambat pengelolaan bidikmisi}

Penyelenggaraan program besar biasanya tidak selalu bisa berjalan dengan baik, begitu juga program Bidikmisi. Beberapa faktor yang muncul sebagai faktor penghambat pengelolaan program bidikmisi Unesa antara lain.

1. Kurangnya koordinasi

Koordinasi terkait jumlah pasti penerima bidikmisi juga hal yang penting, beberapa kali terjadi data jumlah dan nama penerima bidikmisi tidak sama antar pihak terkait di Unesa, bidang keuangan, bidang akademik, bidang kemahasiswaan, dan PPTI. Terdapat pula perbedaan data penerima Bidikmisi di Unesa dengan yang ada dalam SIM Bidikmisi Belmawa.Hal ini menunjukkan kurangnya koordinasi antara pengelola dengan penyelenggara program di pusat.Adanya perbedaan data tersebut diperlukan koordinasi, singkronisasi atau rekonsiliasi data antara pihakpihak terkait di Unesa dan pengelola pusat untuk menghasilkan data yang valid.

2. Kurangnya informasi dan komunikasi. Informasi dan komunikasi adalah sesuatu yang sangat berperan dalam pelaksanaan program, terlebih untuk pelaksanaan program Bidikmisi dengan jumlah penerima yang sangat banyak. Berdasarkan hasil penelitian ditemukan kurangnya informasi yang diberikan kepada penerima Bidikmisi baru maupun penerima Bidikmisi lama (on going). Informasi yang disebarkan oleh pengelola belum tersusun secara resmi, kadang hanya berupa informasi informal yang disebar melalui media sosial seperti WAG mahasiswa, dan ini menimbulkan simpang siurnya informasi. Hal ini terjadikarena belum adanya panduan teknis pengelolaan Bidikmisi di Unesa.Adanya informasi yang berkembang dan beredar di mahasiswa penerima Bidikmisi Unesa yang belum jelas sumbernya mengindikasikan bahwa informasi dan komunikasi pengelolaan Bidikmisi belum terwujud dengan baik. Diperlukan adanya panduan pengelolaan Bidikmisi Unesa yang mencakup proses pengusulan, mekanisme pencairan dana, monev, cara penggantian, dan kelulusan.

3. Lemahnya sistem monitoring dan evaluasi. Diperlukan sistem monitoring dan evaluasi (monev) Bidikmisi yang tepat sehingga dapat mengukur ketepatan dalam pengelolaan Bidikmisi. Monev menjadi bagian penting dalam penyelenggaraan program besar termasuk program Bidikmisi ini. Monev dilaksanakan dalam rangka untuk mengetahui sejauh mana pelaksanaan program bidikmisi dapat dijalankan dan sejauh mana perkembangan kuliah mahasiswa penerima Bidikmisi. Namun demikian terdapat mahasiswa penerima Bidikmisi belum mengetahui adanya Monev Bidikmisi Unesa. Monev Bidikmisi dilakukan oleh Ditjen Belmawa dan Unesa yang dilakukan setiap akhir semester dengan melihat hasil studi. Apabila ada mahasiswa Bidikmisi hasil studinya IPK kurang dari 3.00 maka mereka akan diundang ke Rektorat Unesa untuk dilakukan klarifikasi atas IPK tersebut. Sistem monev Bidikmisi Unesa perlu dilakukan dengan melibatkan pihak fakultas. BAKPK setelah memperoleh data IPK 
mahasiswa Bidikmisi melalui SIAKADU, maka dilakukan filter IPK yang kurang dari 3.00. Selanjutnya data IPK tersebut dikirim BAKPK ke Wakil Dekan Bidang Kemahasiswaan dan Alumni Fakultas untuk ditindaklanjuti dan diberikan rekomendasi. Hasil dari tindaklanjut fakultas tersebut selanjutnya dikirim ke Wakil Rektor Bidang Kemahasiswaan dan Alumni untuk dievaluasi lebih lanjut, sehingga dapat diketahui apakah penerima Bidikmisi tersebut layak dilanjutkan atau harus dihentikan.

4. Kurangnya komitmen mahasiswa penerima bidikmisi.

Selama perkuliahan, penerima Bidikmisi mempunyai tugas dan tanggungjawab yang harus dilaksanakan seperti harus aktif dalam kegiatan akademik maupun non akademik, indeks pretasi akademik minimal 3.00 setiap semester, serta lulus tepat waktu. Namun demikian, tidak semua mahasiswa Bidikmisi menyadari akan hal tersebut. Bahkan beberapa diantaranya masuk kategori mahasiswa yang memerlukan perhatian disebabkan nilai IPK yang tidak memenuhi syarat, sehingga mahasiswa yang IPK nya di bawah 3.00 akan dipanggil oleh pengelola untuk dilakukan klarifikasi.

\section{KESIMPULAN}

Berdasarkan analisis data dan hasil pembahasan penelitiantentang Efektivitas Program Beasiswa Bidikmisi di Universitas Negeri Surabaya, maka dapat disimpulkan bahwa pengelolaan bantuan biaya pendidikan Bidikmisi di Universitas Negeri Surabaya sudah sesuai dengan petunjuk pengelolalaan yang dikeluarkan oleh Ditjen Belmawa, Kemenristekdikti, sedang efektivitas program beasiswa bidikmisi di Universitas Negeri Surabaya, dapat dilihat dari pencapaian tujuan pemberian bidikmisi, yaitu 1) pemerataan akses pendidikan. Bantuan biaya pendidikan bidikmisi di Unesa telah dapat dirasakan manfaatnya oleh mahasiswa penerima bidikmisi dan 95\% tepat sasaran, 2) lulus tepat waktu. Tingkat lulus tepat waktu mahasiswa Bidikmisi Unesa masih kurang,49,91\% (mahasiswa angkatan 2015), 3) meningkatnya prestasi dan kualitas mahasiswa.Prestasi akademik mahasiswa penerima Bidikmisi Unesa dapat dilihat dari hasil studinya, rata-rata IPK mahasiswa Bidikmisi di atas 3.00, bahkan sampai cumlaude.4) Faktor penghambat pengelolaan.Terdapat beberapa faktor penghambat pengelolaan Bidikmisi Unesa, antara lain kurangnya koordinasi antara pengelola dengan pihak-pihak terkait, kurangnya informasi dan komunikasi yang diberikan kepada penerima bidikmisi, masih belum terlaksananya monitoring dan evaluasi, dan kurangnya komitmen penerima bidikmisi atas tanggungjawabnya sebagai penerima bidikmisi.

\section{SARAN}

Berdasarkan hasil sementara penelitian ini, peneliti memberikan masukan saran sebagai berikut:

1. Perlu adanya peningkatan koordinasi pengelola dengan penyelenggara Bidikmisi di pusat Jakarta, koordinasi para pihak terkait di Unesa seperti bagian akademik, bagian keuangan, bagian kemahasiswaan, dan PPTI.

2. Perlu adanya sosialisasi sistem monitoring dan evaluasi.

3. Perlu adanya kemudahan dan kejelasan informasi pengelolaan bidikmisi di Unesa, sehingga mahasiswa mendapatkan informasi yang pasti.

4. Perlu adanya pemberian konseling secara lebih personal dengan mahasiswa yang membutuhkan perhatian khusus untuk dapat mengatasi masalah internal yang terjadi pada mahasiswa bidikmisi.

5. Perlu adanya panduan bidikmisiUniversitas Negeri Surabaya

\section{DAFTAR RUJUKAN}

Asra, Irawan, \& Purwoto. (2015). Metode Penelitian Survei. In Media.

Baskoro, A. (2016). Efektivitas Program Bidikmisi di Universitas Negeri Yogyakarta. Universitas Negeri 
Yogyakarta.

Edward, I. (1980). Implementing Public Policy. Congressional Quarterly Inc.

Herdianysah, H. (2010). Metodologi Penelitian Kualitatif untuk IImuilmuSosial. Salemba Humanika.

Hermawati, I. (2011). Evaluasi Kelompok Usaha Bersama (KUBE). B2P3KS Press.

Mahmudi. (2005). Manajemen Kinerja Sektor Publik. UPP AMP YKPN.

Moleong, J. (2014). Lexy, Metodologi Penelitian kualitatif, Penerbit PT. Remaja Rosdakarya Bandung.

Salusu, J. (1996). Pengambilan Keputusan Stratejik Untuk Organisasi Publik dan Organisasi Non Profit. Grasindo.

Sandra. (2017). Pola Perilaku Konsumsi Mahasiswa Bidikmisi 2013 (Studi Tentang Mahasiswa Beasiswa Bidikmisi 2013 Universitas Riau. JOM FISIP, 4(2).

Sugiyono. (2012). Metode Penelitian Kuantitatif Kualitatifdan R\&D. Alfabeta. 